\title{
Firms' Output Growth And Financial Ratios
}

Carlos Henrique Rocha, (E-mail: carlosh@ucb.br), Catholic University of Brasília, Brazil Ivan Ricardo Gartner, (E-mail: irgartner@hotmail.com), Catholic University of Brasília, Brazil

\begin{abstract}
The central focus of this paper is on the relationship between output growth of the firm and its financial ratios. The analysis is based on managerial theories of the firm, in particular, on Baumol's (1967) article that suggests sales revenue maximization as a goal of the firm instead of profit maximization. A cross-section equation was estimated for three Brazilian industries covering the year 2000. We regress a firm's output growth on a constant and a vector of financial ratios. The results obtained from ordinary least-squares regressions show firms with good financial performance present higher output growth.
\end{abstract}

\section{Introduction}

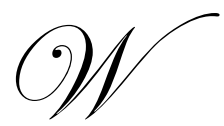

hile most people assume that the firm's objective is to maximize profits, some others argue that firms, especially large corporations, have other goals rather than profit maximization. One of the more commonly postulated models is that, given the attainment of a satisfactory level of profits, firms seek to maximize sales revenue (Baumol, 1967; Marris, 1963).

The distinguishing characteristic of large corporations is a divorce of ownership from control. The owners bear the risks, in the sense that fluctuations in the profits of the company imply fluctuations in their income (dividends) from it. They also supply the risk capital for new investment, either by buying new issues of shares, or, more usually, by agreeing to forego profits which are then ploughed back into the business. The owners are the shareholders, whose power lies in appointing the board of directors, which in turn appoints the top management. The most important member of the firm is top management, because of its power in decision-making and access to information.

The divorce of ownership from management permits the top managers to deviate from profit maximization and pursue goals, which maximize their own utility. However, the managers' discretion in defining the goals of the firm is not unlimited. A minimum level of profit is necessary for a dividend policy acceptable to the body of shareholders.

In principle, the top executives subject to a minimum profit level determined by the shareholders carry out all of the entrepreneurial functions of the capitalist; for instance, decisions on investment and expansion. ${ }^{1}$ In short, these are some of the tenets of managerial theories of the firm (Baumol, 1967; Marris, 1963; Marris, 1964; Williamson, 1973). ${ }^{2}$

Based on managerialism, in particular, on Baumol's (1967) article that suggests sales revenue maximization as a goal of the firm subject to a minimum level of profit that keep shareholders happy, this paper examines empirically the relationship between firm's output growth and a vector of financial ratios.

The plan of paper is as follows. In the next section the theoretical framework is provided. Section 3 discusses the empirical results while section 4 concludes.

$\overline{\text { Readers with comments }}$ or questions are encouraged to contact the authors via email.

\footnotetext{
${ }^{1}$ Actually, the executives do not perform one function that is of supplying the risk capital of the business.

${ }^{2}$ Managerial theories predict other goals that a firm can pursue, relating to market share, technology (providing the most technologically advanced products), costumer satisfaction and shareholder value (maximizing the price of its stock).
} 


\section{The Theoretical Framework}

We consider a top management whose chooses the level of sales revenue $R_{i}^{j} \in R^{n}$, subject to a financial policy constraint curbed by the interests of the owners

Maximize $U_{i}^{j}(R, \bar{\phi}), \quad$ subject to $h_{i}^{j}(R, \bar{\phi})$

where $U_{i}^{j}($.$) is the managerial utility function of the ith firm in the jth industry, h_{i}^{j}($.$) is the financial policy$

imposed by the owners and $\bar{\phi}_{i}^{j}=\left(\bar{\phi}_{i 1}^{j}, \ldots \bar{\phi}_{i k}^{j}\right)$ is a vector of financial ratios. $U_{i}^{j}($.$) and h_{i}^{j}($.$) are real-valued$ and continuously differentiable functions on $R^{n}$.

The solution of this maximization problem $R_{i}^{j^{*}}$ bears upon the values of such financial ratios, namely

$R_{i}^{j^{*}}=R(\bar{\phi})$

Now, let be the rate of capital formation of the ith firm in the jth industry given by

$\frac{d k_{i}^{j} / d t}{k}=\alpha_{i}^{j} R_{i}^{j^{*}}\left(\bar{\phi}_{1}, \ldots \bar{\phi}_{k}\right)$

where $k_{i}^{j}$ is physical capital and $\alpha_{i}^{j}$ is a scalar between 0 and 1. Equation [3] says that a fraction of sales revenue $R_{i}^{j^{*}}$ goes to capital formation and as such denotes the top executives power in decision-making, say, in decisions on investment and expansion of the firm, as supposed in managerial theories of the firm.

As in the tradition growth theory (Solow, 1956; 1957), we assume that capital formation takes a crucial part of the firm output growth, so

$$
\frac{d y_{i}^{j} / d t}{y_{i}^{j}}=f_{i}^{j}\left(\bar{\phi}_{1}, \ldots \bar{\phi}_{k}\right), f_{i{ }_{1}}{ }^{j}, \ldots, f_{i k}{ }^{j}>0
$$

where $y_{i}^{j}$ is the level of output of the ith firm in the jth industry and an increase in a financial ratio will lead to output growth. The top managers attitude act as an engine on economic growth.

Therefore, equation [4] will be used to ascertain the output growth of the ith firm in the jth industry; that is, [4] is our target estimation.

\section{Empirical Analysis}

The regression model is of the form

$$
\Delta y_{i}^{j}=\beta_{0}+\beta_{1} \Delta \phi_{i 1}^{j}+\ldots+\beta_{k} \Delta \phi_{i k}^{j}+\beta_{k+1} D_{i}^{j}+\varepsilon
$$


where $\Delta y_{i}^{j}$ is change in output (as a proxy: sales revenue) of the ith firm in the jth industry, $\Delta \phi_{i}^{j}$ is the deviation of the financial ratio of the ith firm from the financial ratio of the leading firm in the jth industry (that is, the desired financial ratio) and $D_{i}^{j}$ is a dummy variable to account for other factors that are common across firms in a given industry, $\ln$ is natural logarithm and $\varepsilon$ is the error-term.

On a priori grounds we expect a positive relationship between output changes and the deviation of firm's financial ratio from the desired financial ratio.

We consider six financial ratios. They are: $\phi_{1}=$ profit margin on sales, $\phi_{2}=$ investments turnover, $\phi_{3}=$ return on investments, $\phi_{4}=$ return on equity, $\phi_{5}=$ debt ratio (for this financial ratio one should expect a negative relationship with output growth) and $\phi_{6}=$ current liquidity.

We used data from the July 2001 edition of Revista Exame 500 Maiores which contains data for the year 2000. We then ran cross-section regressions of Brazilian firms for three industries: food, manufacturing, retailers and chemical producers.

In Table 1 we report the results for equation [5]. For the dummy variable we have assigned the value of one to firms which experienced high output growth and zero for the remaining firms in the industry. $\eta_{1}$ is the RESET test of functional form and $\eta_{2}$ is Goldfeld-Quandt test for heteroscedasticity. ${ }^{3}$

Table 1

$$
\Delta y_{i}^{j}=b_{0}+b_{1} \Delta \phi_{i 1}^{j}+\ldots+b_{k} \Delta \phi_{i k}^{j}+b_{k+1} D_{i}^{j}
$$

(Dependent variable: change in sales revenue)

\begin{tabular}{|c|c|c|c|c|c|c|c|c|}
\hline \multicolumn{9}{|c|}{ Food Manufacturing $(N=25)$} \\
\hline$b_{0}$ & $b_{1}$ & $b_{2}$ & & Dum & & $R^{2}$ & $\begin{array}{l}\eta_{1} \\
F(1,20)\end{array}$ & $\begin{array}{l}\eta_{2} \\
F(8,12)\end{array}$ \\
\hline $\begin{array}{l}0.90 \\
(17.57)\end{array}$ & \begin{tabular}{|l}
1.10 \\
$(2.24)$ \\
\end{tabular} & \begin{tabular}{|l|l}
0.14 \\
$(2.83$ \\
\end{tabular} & & $\begin{array}{l}0.42 \\
(6.24)\end{array}$ & & 0.70 & 1.92 & 0.64 \\
\hline \multicolumn{9}{|c|}{ Retailers ( $N=29$ ) } \\
\hline$b_{0}$ & $b_{3}$ & & Dummy & & $R^{2}$ & & $\begin{array}{l}\eta_{1} \\
F(1,25)\end{array}$ & $\begin{array}{l}\eta_{2} \\
F(4,21)\end{array}$ \\
\hline $\begin{array}{l}0.91 \\
(25.76)\end{array}$ & \begin{tabular}{|l|}
1.51 \\
$(6.23)$
\end{tabular} & & $\begin{array}{l}0.25 \\
(5.08)\end{array}$ & & 0.75 & & 1.65 & 0.17 \\
\hline \multicolumn{9}{|c|}{ Chemical Producers ( $N=33$ ) } \\
\hline$b_{0}$ & $b_{4}$ & & Dummy & & $R^{2}$ & & $\begin{array}{l}\eta_{1} \\
F(1,29)\end{array}$ & $\begin{array}{l}\eta_{2} \\
F(4,25)\end{array}$ \\
\hline $\begin{array}{l}0.90 \\
(18.73)\end{array}$ & $\begin{array}{l}0.13 \\
(1.81)\end{array}$ & & $\begin{array}{l}0.35 \\
(5.74)\end{array}$ & & 0.59 & & 0.25 & 1.79 \\
\hline
\end{tabular}

t ratios (Student statistics) in brackets.

The statistics reported in Table 1 suggest that the models are well specified, since no diagnostic test was

\footnotetext{
${ }^{3}$ See Stewart (1991).
} 
significant at the $5 \%$ level of significance. The results show that indeed financial ratios account for growth. For food manufacture firms' output growth is sensitive to two financial ratios: profit margin on sales and investments turnover. In the case of retailer firms output growth responds to the return on investments financial ratio whilst for chemical producers which matter is the return on equity financial ratio. We may say that the results provide evidence supporting Baumol's (1967) claim.

\section{Conclusions}

The central focus of the paper is on the relationship between output growth of the firm and its financial ratios. The analysis is grounded on Baumol's (1967) claim that suggests sales revenue maximization as a goal of the firm instead of profit maximization. A cross-section model was estimated for three Brazilian industries, food manufacturing, retailers and chemical producers. The empirical evidence reported here is in favor of the relationship between firm's output growth and its financial ratios. In sum, firms with good financial performance present higher output growth.

\section{References}

1. Baumol, W. J. (1967). Business Behavior, Value and Growth, Harcourt Brace Javanovich.

2. Marris, R. (1963). A Model of the 'Managerial' Enterprise, Quarterly Journal of Economics, 77, 185-209.

3. Marris, R. (1964). Theory of 'Managerial' Capitalism, Macmillan.

4. Solow, R. (1956). A Contribution to the Theory of Economic Growth, Quarterly Journal of Economics, 70, 65-94.

5. Solow, R. (1957). Technical Change and Aggregate Production Function, Review of Economics and Statistics, 39, 312-20.

6. Stewart, J. (1991). Econometrics, Philip Allan.

7. Williamson, O. E. (1973). Managerial Discretion and Business Behavior. In Gilbert, M. (ed.) The Modern Business Enterprise, Penguin. 